\title{
Design and Construction of Single Phase Radial Flux Permanent Magnet Generators for Pico hydro Scale Power Plants Using Propeller Turbines in Water Pipes
}

\author{
EkoYohanes Setyawan ${ }^{1,}$, Yusuf Ismail Nakhoda ${ }^{2}$, Awan Uji Krismanto ${ }^{2}$, Lalu Mustiadi $^{1}$, \\ Erkata Yandri $^{3}$, and Juris Burlakovs ${ }^{4}$ \\ ${ }^{1}$ Mechanical Engineering Department, National Institute of Technology Malang, Jl. Sigura-Gura \\ No.2, Malang 65145, East Java, Indonesia \\ ${ }^{2}$ Electrical Engineering Department, National Institute of Technology Malang, Jl. Sigura-Gura No.2, \\ Malang 65145, East Java, Indonesia \\ ${ }^{3}$ Graduate School of Renewable Energy, Darma Persada University, Jl. Radin Inten 2, \\ Pondok Kelapa, East Jakarta 13450, Indonesia \\ ${ }^{4}$ Department of Water Management, Estonian University of Life Sciences, Tartu, Estonia; \\ Friedrich Reinhold Kreutzwaldi 1a, 51014 Tartu, Estonia
}

\begin{abstract}
Pico hydro or a small scale hydroelectric power plant is used as the rotating energy of the generator. Pico hydro is a hydroelectric power plant that has a power of less than $5 \mathrm{~kW}$. Technically, Pico hydro has three main components namely water, turbine and generator. Turbine type propeller reaction has a special profile that causes a decrease in water pressure during the blades. This pressure difference exerts force on the blade so that the runner (rotating part of the turbine) can rotate. Permanent magnets are used to produce magnetic flux. Permanent magnets used are rare-eatrhrod magnet material, neodymium-iron-boron $\mathrm{NdFeB}$ with $\mathrm{N} 35$ type. The planned generator released is $36.85 \mathrm{~V}, 500 \mathrm{rpm}, 50 \mathrm{hz}$. This designed water turbine has four blades which cannot change its angle. As for the measurement results produce a voltage of $35.1 \mathrm{~V}$ with a manufacturing efficiency of $95 \%$. Charging the battery voltage must be more than $12 \mathrm{~V}$, therefore the generator must be turned at least $200 \mathrm{rpm}$ with a voltage of $14 \mathrm{~V}$ to be used for charging batteries.
\end{abstract}

Keywords: Charging, hydroelectric power plant, neodymium, turbine type propeller, renewable energy

\section{Introduction}

Nowadays, population grows rapidly along with the housing growth. This condition causes the electricity providers increase the power capacity, therefore the need on innovation generators or micro-scale generators is considered important. Generator is still less used, especially in areas of Indonesia that have many renewable energy sources. One of the

*Corresponding author: yohanes@lecturer.itn.ac.id 
energy sources is water energy that is not utilized optimally, instead of the fact that microhydro power plants are a type of renewable power plants that are environmentally friendly, easy to operate and low in operating costs. Initial survey held in river in Manokwari, Indonesia shows that the river has a hydraulic potential of around $29.5 \mathrm{~kW}$. According to the results, a micro-hydro power plant has been planned at this location. The power plant will use a hydraulic potential of $25.2 \mathrm{~kW}$ based on a flow rate of $0.3 \mathrm{~m}^{3} \mathrm{~s}^{-1}$ and a head height of $8.6 \mathrm{~m}[1,2]$.

The use of small-scale generators will be very helpful to the society if it is well developed since it is easy to maintain, control, and to obtain the materials [3-5]. The generators on the market today are generators that have high rpm and require initial electrical energy to create their magnet field. Harmonic step-time generator models are applied to induction and mechanical rotor electric generators for error measurement, and propose simple closed-form analytic expressions for illustrate. The prediction was then validated by testing on a $30 \mathrm{~kW}$ induction generator test rig [6].

Hydroelectric power generation is a proven and inexpensive technology that does not damage the environment or in other words, environmentally friendly. It supports energy diversification by utilizing renewable energy, supports programs to reduce the use of engine fuels, and mostly uses local resource content. The great potential of water energy in Indonesia is $74976 \mathrm{MW}$ as much as $4200 \mathrm{MW}(5.6 \%)$ in Java, while the amount of the exploitation is only around $5000 \mathrm{MW}$ (7\% of the existing potential) [7].

The construction of each type of electricity generator is based on the technical and economic feasibility of the electricity center and the results of analytical studies on energy needs. The basic consideration is the availability of a particular energy source, the need (demand) for electrical energy, costs, as well as the special characteristics of each type of plant to support the electric power load. In addition to hydropower, pico hydro energy (pico hydro power plant) which the capacity is less than $5 \mathrm{~kW}$ have the potential of $458.75 \mathrm{MW}$. Therefore pico hydro is very feasible to be developed to meet the needs of electricity in remote or rural areas on small islands with narrow river flow [8].

Run of river types of electricity planters are widely used in pico hydro-scale hydroelectric power plants in waterways/canals. This type of electricity generates electricity by naturally utilizing the river itself. The investment costs for developing the pico hydro power plant are relatively cheaper compared to the investment costs for hydropower. This is due to the simplification of construction standards and output power that is adjusted to rural conditions [9].

\section{Research method}

The generator is a rotating electric engine that can convert mechanical energy or motion into electrical energy using the principle of electromagnetic induction. Alternating voltage generators produce alternating poles, called AC voltages. The main part of an AC generator consists of a permanent magnet, a coil, an iron core and a generator housing. In the generator the change in the line of magnetic force (flux) is obtained by rotating the permanent magnet (rotor) in the stator coil field, therefore the rotation of the permanent magnet causes an induction of electromotive force. Then the induced current generated in the form of alternating current positive and negative poles [10].

\subsection{Radial flux permanent magnet (RFPM) generator}

The need for generators is currently growing rapidly in meeting the availability of electricity. Many studies began to be developed to get a generator that can be operated at high and low rotation. RFPM generator is a permanent magnet generator that has a radial 
flux direction towards the rotating axis so that the flux direction is in the direction of rotation of the rotor. This is caused by the flux generated by the inner magnetic magnet of the rotor whose construction is circling around the outer winding; whereas for the winding there is an inner core connected rotor center. This type of machine has a strong structure and simple shape. Radial flux machine is a machine that does not have a difference in rotational speed of the rotor with the strong speed of the stator magnetic field (synchronous) where the magnetic field gives the radial direction by placing the stator around the rotor. Radial flux generators can be applied at low or high turns as shown in Figure 1.

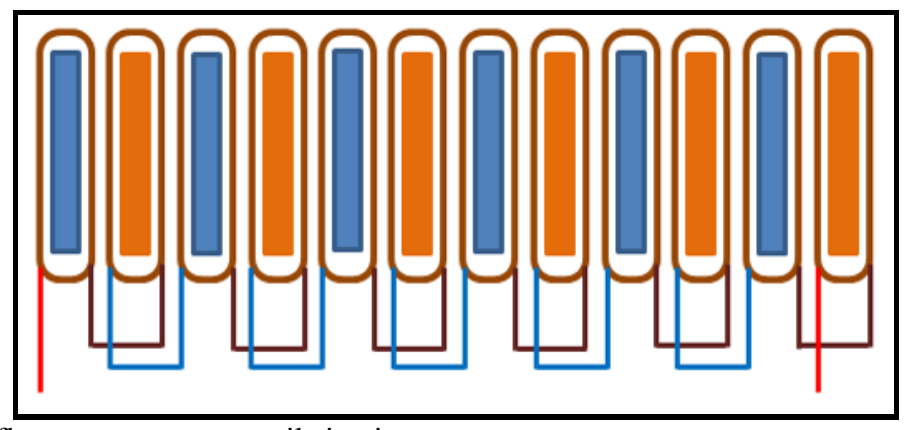

Fig. 1. Radial flux generator stator coil circuit.

A generator test is carried out to find out the energy produced by water turbines and to find out how much voltage is flowing both the minimum voltage and the maximum voltage. This test is done without using a load of lights but directly battery, it aims to see the loading effect on the power and current generated by the generator on the battery in Figure 2 .

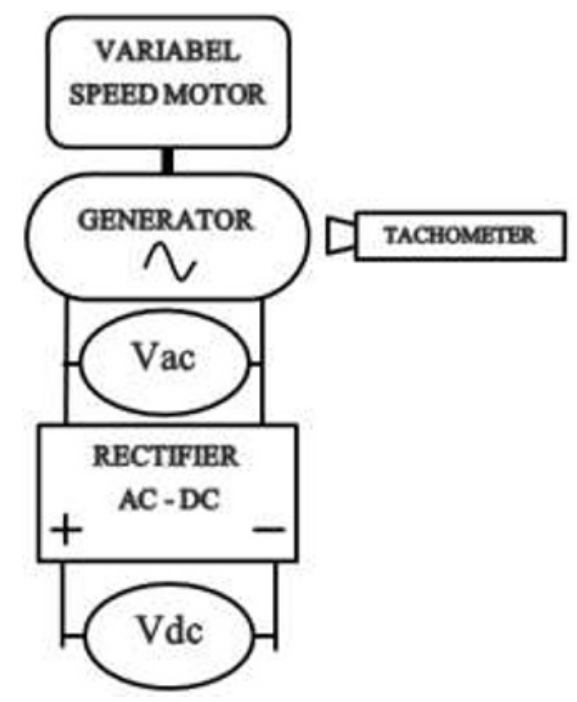

Fig. 2. Block diagram of generator testing.

\subsection{Testing of pico hydro scale power plants}

The test is done by arranging and connecting the output of the Pico hydro power plant with measuring devices such as a multimeter and tachometer to determine the voltage and 
current in accordance with Figure 3. By measuring the rotation speed of a water turbine and the output voltage and current on a power plant on a water turbine.

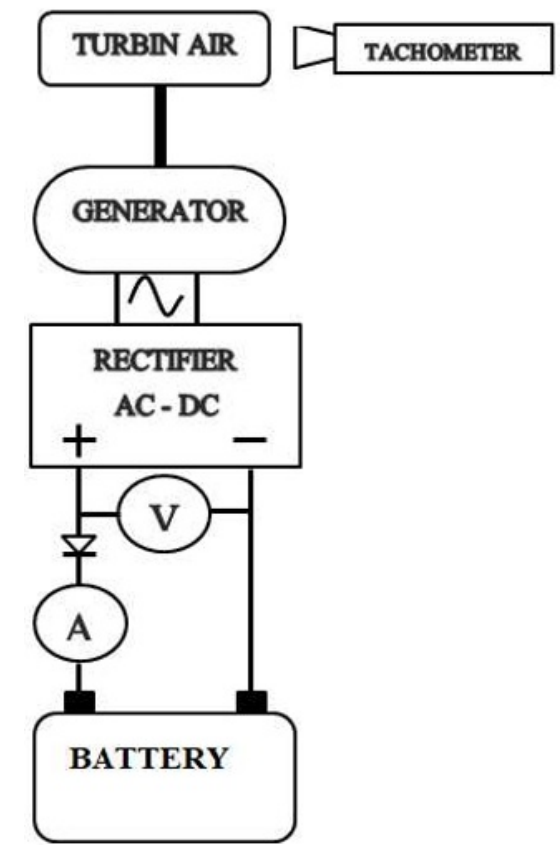

Fig. 3. Block diagram of pico hydro power plant testing.

\subsubsection{Generator rotational speed}

The basic principle of an AC generator is using the relationship between the rotational speed of the rotor and the frequency of the generator. The rotational speed of the stator field strength and the frequency of the generator which is inversely proportional to the number of poles based on the rotation of the minute can be stated in Equation (1):

$$
\mathrm{n}_{\mathrm{g}}=\frac{120 \times \mathrm{f}}{\mathrm{p}}(\mathrm{rpm})
$$

$\mathrm{n}_{\mathrm{g}}$ is the generator rotation $(\mathrm{rpm}), \mathrm{f}$ is the frequency $(\mathrm{Hz})$ and $\mathrm{p}$ is the number of magnetic poles $(1 \mathrm{rpm}=1 / 60 \mathrm{~Hz})$

\subsubsection{Permanent magnet rotors}

In generating a magnetic field in a magnetic generator, the type of magnet used to produce magnetic flux is a neodymium magnet. Neodymium magnets, also known as $\mathrm{NdFeB}$, are used as rare-earth material bar magnets, neodymium-iron-boron type magnets, a type of rare earth magnet, made with a mixture of neodymium metal. Tetragonal $\mathrm{Nd} 2 \mathrm{Fe} 14 \mathrm{~B}$ has a very high uniaxial structure of magnetocrystalline anisotropy (HA 7 T). This compound provides the potential to have high coercivity, namely resistance to magnetic damage.

\subsubsection{Maximum flux density}

The maximum magnetic flux density values in Equation (2): 


$$
\mathrm{B}_{\max }=\mathrm{B}_{\mathrm{r}} \times \frac{\mathrm{L}_{\mathrm{m}}}{\mathrm{L}_{\mathrm{m}}+\delta}(\mathrm{T})
$$

$\mathrm{B}_{\max }$ is the flux density $(\mathrm{T}), \mathrm{B}_{\mathrm{r}}$ is residual induction $(\mathrm{T}), \mathrm{L}_{\mathrm{m}}$ is the magnetic high $(\mathrm{m})$ and $\delta$ is the air gap $(\mathrm{m})$.

\subsubsection{Area of magnetic field}

Designing the location of permanent magnets on the generator rotor as in Equation (3):

$$
A_{\text {magn }}=\frac{\pi\left(\mathrm{ro}^{2}-\mathrm{ri}^{2}\right)-\tau \mathrm{f}(\mathrm{ro}-\mathrm{ri}) \mathrm{N}_{\mathrm{m}}}{\mathrm{N}_{\mathrm{m}}}\left(\mathrm{m}^{2}\right)
$$

$\mathrm{A}_{\text {magn }}$ is the area of the magnet $\left(\mathrm{m}^{2}\right), \pi$ phi (3.14), ri is the radius in the magnet (m), ro is the outer radius of the magnet $(\mathrm{m}), \tau \mathrm{f}$ is the distance between magnets $(\mathrm{m})$ and $\mathrm{N}_{\mathrm{m}}$ is the amount of magnetism.

\subsubsection{Maximum flux}

To find the maximum flux of a permanent magnetproduced uses the Equation (4):

$$
\emptyset_{\text {max }}=A_{\text {magn }} \times B_{\text {max }}(\mathrm{Wb})
$$

$\emptyset_{\max }$ is the maximum flux $(\mathrm{Wb}), \mathrm{A}_{\text {magn }}$ is the area of the magnet $\left(\mathrm{m}^{2}\right)$ and $\mathrm{B}_{\max }$ is the flux density (T).

\subsubsection{Number of stator coils}

To find the number of stator coils $\left(\mathrm{N}_{\mathrm{s}}\right)$ needed uses the Equation (5):

$$
\mathrm{N}_{\mathrm{s}}=\mathrm{p} \times \frac{\mathrm{N}_{\mathrm{ph}}}{2}
$$

$\mathrm{N}_{\mathrm{s}}$ is the number of stator coils, $\mathrm{N}_{\mathrm{ph}}$ is the number of phases and $\mathrm{p}$ is the number of phases and $\mathrm{p}$ is the number of magnetic poles. Copper wire is one of the many types of electrical conductors based on the material. This type of wire is the first metal used as wire and cable material. The function of copper wire is often used for winding materials in electric generators. Determining the number of turns $(\mathrm{N})$ is one of the most important things in the design of the radial flux generator in which the number of turns is influenced by several parameters such as the extent of the soft iron core to be used. If the area of the iron core is fixed, the number of turns increases, the smaller the copper wire used, and vice versa, the less the coil, the greater the size of the copper wire.

\subsubsection{Induction voltage}

As for the voltage from the induction generator on the generator being generated can be calculated through the Equation (6):

$$
\mathrm{E}_{\mathrm{rms}}=4.44 \times \mathrm{N} \times \mathrm{f} \times \emptyset_{\max } \times \frac{\mathrm{N}_{\mathrm{s}}}{\mathrm{N}_{\mathrm{ph}}}(\mathrm{V})
$$

$\mathrm{E}_{\mathrm{rms}}$ is the voltage from the induction generator $(\mathrm{V}), \mathrm{N}$ is the number of turns, $\mathrm{f}$ is the frequency $(\mathrm{Hz}), \emptyset_{\max }$ is the maximum flux $(\mathrm{Wb}), \mathrm{N}_{\mathrm{s}}$ is the number of stator coils and $\mathrm{N}_{\mathrm{ph}}$ is the number of phases. 


\subsubsection{One phase power generator}

As for the power from the generator being generated, it can be calculated through the following Equation (7)[11]:

$$
\mathrm{S}_{1 \varnothing}=\mathrm{V}_{\mathrm{L}-\mathrm{N}} \times \mathrm{I}(\mathrm{VA})
$$

$\mathrm{S}_{1 \varnothing}$ is the power generator $(\mathrm{VA}), \mathrm{V}_{\mathrm{L}-\mathrm{N}}$ is generator voltage $(\mathrm{V})$ and $\mathrm{I}$ is the current $(\mathrm{A})$.

\subsection{The Performance of pico hydro powerplant}

\subsubsection{Water discharge}

Water discharge level (Q) can be obtained in different ways but a more suitable method can be measured by the speed of water flow from the river by being placed in a water pipe that has a cross-sectional area of the river in the same measurement place, by using the following in Equation (8) [12]:

$$
\mathrm{Q}=\mathrm{v} \times \mathrm{A}\left(\mathrm{m}^{3} \mathrm{~s}^{-1}\right)
$$

$\mathrm{Q}$ is the flow rate of water $\left(\mathrm{m}^{3} \mathrm{~s}^{-1}\right), \mathrm{A}$ is the area of the pipe cross-section rapidly $\left(\mathrm{m}^{2}\right)$ and $\mathrm{v}$ is the velocity of water flow $\left(\mathrm{m} \mathrm{s}^{-1}\right)$.

\subsubsection{Height of the rapid pipe}

The height of the waterfall is also called water pressure which is created by the elevation difference between the water level intake and the house of the water turbine. High water can be obtained with vertical distance or as pressure. Regardless of the size of the water discharge, the higher will produce greater pressure, and therefore higher power output in the water turbine. It can be calculated by using the following in Equation (9):

$$
\mathrm{H}_{\mathrm{n}}=\mathrm{H}_{\mathrm{g}}-\mathrm{H}_{\text {loss }}(\mathrm{m})
$$

$\mathrm{H}_{\mathrm{n}}$ is the effective height $(\mathrm{m}), \mathrm{H}_{\mathrm{g}}$ is gross height $(\mathrm{m})$ and $\mathrm{H}_{\text {loss }}$ is a high loss, around $6 \%$ from the gross height $(\mathrm{m})$.

\subsubsection{Turbine specific speed}

The specific speed gives an indication of the turbine's geometry and that is the starting point for detailed design. There are various ways to determine the specific speed $\left(\mathrm{n}_{\mathrm{s}}\right)$ of a hydro turbine. For this design, using the following Equation (10):

$$
\mathrm{n}_{\mathrm{s}}=\frac{\mathrm{n}_{\mathrm{t}} \times \sqrt{\mathrm{Q}}}{\mathrm{H}_{\mathrm{n}}{ }^{3 / 4}}
$$

$\mathrm{n}_{\mathrm{S}}$ is the specific speed, $\mathrm{n}_{\mathrm{t}}$ is the turbine speed (rpm), Q is the water discharge $\left(\mathrm{m}^{3} \mathrm{~s}^{-1}\right)$ and $\mathrm{H}_{\mathrm{n}}$ is the effective height (m).

\subsubsection{Turbine runner diameter}

Determine the diameter of the runner ( $\left.\mathrm{D}_{\text {runner }}\right)$ can be done in various ways. One of the more popular ones for calculating turbine outer propeller diameters is in Equation (11): 


$$
D_{\text {runner }}=\sqrt{\frac{\mathrm{Q}}{2.2 \times \sqrt{H_{n}}}}(\mathrm{~m})
$$

$D_{\text {runner }}$ is the outer diameter of the blades $(m), n_{s}$ is the specific speed, $n_{t}$ is the turbine speed (rpm), and $\mathrm{H}_{\mathrm{n}}$ is the effective height $(\mathrm{m})$.

\subsubsection{Diameter hub turbin}

Diameter hub $\left(\mathrm{D}_{\text {hub }}\right)$ is the shaft of propeller type water turbine that can be estimated by the following in Equation (12):

$$
\mathrm{D}_{\text {hub }}=\left(0.25+\frac{0.0951}{\mathrm{n}_{\mathrm{s}}}\right) \times \mathrm{D}_{\text {runner }}(\mathrm{m})
$$

$\mathrm{D}_{\text {runner }}$ is the outer diameter of the blades $(\mathrm{m})$ and $\mathrm{D}_{\text {hub }}$ is inner diameter of the blade $(\mathrm{m})$.

\section{Results and discussion}

The results of testing of one phase permanent magnet radial flux generators were carried out to compare the results of the generator planning with the generator measurements. In testing and measuring the generator, the measuring tool must be in good condition to improve the accuracy of the test. Generator measurements are carried out on the day and Wednesday, May 17, 2018. Retrieval of voltage, current and rpm data is carried out for $1 \mathrm{~h}$ (15.30 to 16.30) West Indonesian Time to determine the characteristics of the generator located on campus 2 National Institute of Technology Malang, Electro, Electrical Energy Conversion Laboratory on the first floor. Table 1 shows the results of the measurement of the generator without load.

Table 1. Results of the measurement of the generator without load.

\begin{tabular}{|c|c|c|c|c|}
\hline No & $\mathrm{rpm}$ & $\mathrm{Hz}$ & $\mathrm{V} \mathrm{ac}$ & $\mathrm{V} \mathrm{dc}$ \\
\hline 1 & 100 & 10 & 7.6 & 6.2 \\
\hline 2 & 200 & 20 & 14.5 & 12.1 \\
\hline 3 & 300 & 30 & 21.6 & 18.5 \\
\hline 4 & 400 & 40 & 28.7 & 25.3 \\
\hline 5 & 500 & 50 & 35.1 & 31.1 \\
\hline 6 & 600 & 60 & 42.4 & 37.4 \\
\hline 7 & 700 & 70 & 49.5 & 43.5 \\
\hline 8 & 800 & 80 & 56.1 & 49.7 \\
\hline 9 & 900 & 90 & 63.3 & 56.2 \\
\hline 10 & 1000 & 100 & 70.4 & 62.2 \\
\hline
\end{tabular}

Data obtained from the measurement results on the day and date Wednesday, May 17, 2018 shows that with the rotational speed of $500 \mathrm{rpm}$, voltage obtained is $35.1 \mathrm{~V} \mathrm{AC}$ and the generator operating frequency at $50 \mathrm{~Hz}$. Factors in Construction Construction where $\mathrm{K}_{\mathrm{s}}$ is a reduction factor ( 0.85 to 0.95$), \mathrm{E}$ is a measurement voltage of $35.1 \mathrm{~V}, \mathrm{E}_{\mathrm{rms}}$ is a planning voltage of $36.85 \mathrm{~V}$, with Equation (13): 


$$
\mathrm{K}_{\mathrm{s}}=\frac{\mathrm{E}}{\mathrm{E}_{\mathrm{rms}}}
$$

Figure 4 is obtained from the results of measurements on May 17, 2018. It shows that the rotational speed of the generator (rpm) is directly proportional to the voltage (V) i.e. the higher the rpm the higher the voltage. Charging the battery voltage must be more than $12 \mathrm{~V}$, the generator must be turned at least $200 \mathrm{rpm}$ with a voltage of $14 \mathrm{~V}$ so that it can be used for charging batteries. Measurements of all devices ranging from generators and hydroelectric power plants on a pico hydro scale using propeller-type water turbines conducted on June 29, 2018 data collection of voltage, current, and rpm carried out for $1 \mathrm{~h}$ (15.00 to 16.00) West Indonesian Time to determine the characteristics of all electricity generation, while the location used to apply the tool is in the Brantas River, Punten Village, Bumiaji District, Batu City and the measurement results are presented in Table 2.

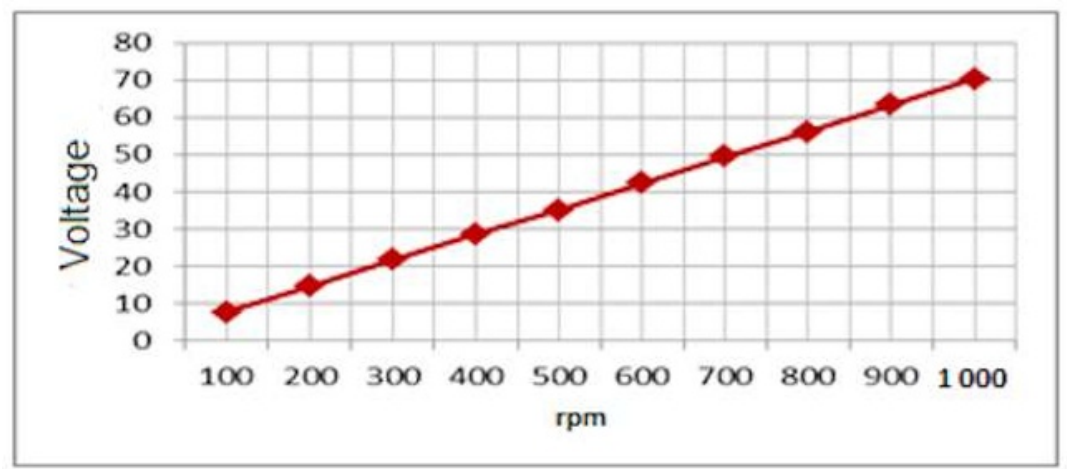

Fig. 4. Graph of AC voltage and rpm of the generator without load.

Table 2. Test results for charging the pico hydro-scale power plant batteries.

\begin{tabular}{|c|c|c|c|c|c|}
\hline No & Time & $\mathrm{rpm}$ & $\mathrm{V} \mathrm{ac}$ & V battery & $\mathrm{I}$ \\
\hline 1 & 15.00 & 204 & 12.3 & 10.54 & 0.10 \\
\hline 2 & 15.05 & 233 & 12.8 & 10.57 & 0.13 \\
\hline 3 & 15.10 & 224 & 12.6 & 10.59 & 0.12 \\
\hline 4 & 15.15 & 240 & 13.2 & 10.63 & 0.14 \\
\hline 5 & 15.20 & 200 & 12.2 & 10.65 & 0.11 \\
\hline 6 & 15.25 & 213 & 12.4 & 10.68 & 0.13 \\
\hline 7 & 15.30 & 240 & 13.1 & 10.70 & 0.13 \\
\hline 8 & 15.35 & 240 & 13.0 & 10.72 & 0.14 \\
\hline 9 & 15.40 & 225 & 12.7 & 10.75 & 0.12 \\
\hline 10 & 15.45 & 218 & 12.5 & 10.77 & 0.11 \\
\hline
\end{tabular}




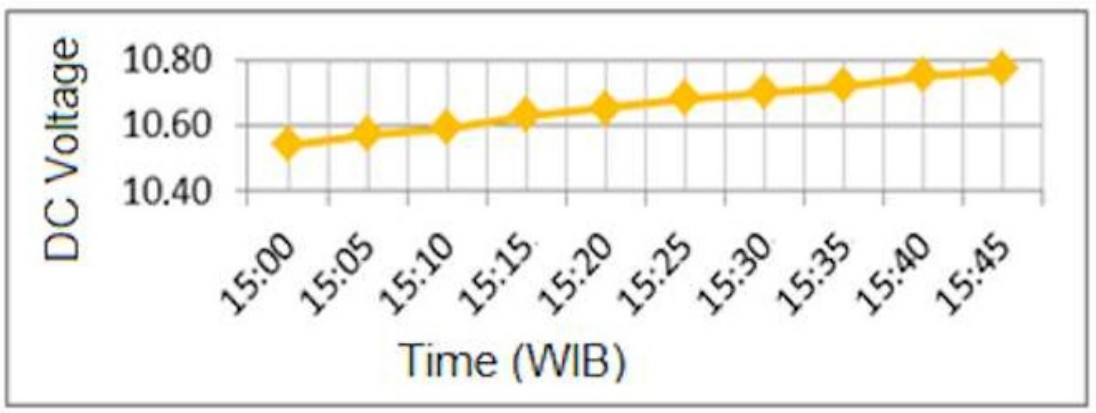

Fig. 5. Graph of voltage and time of generators with water turbines.

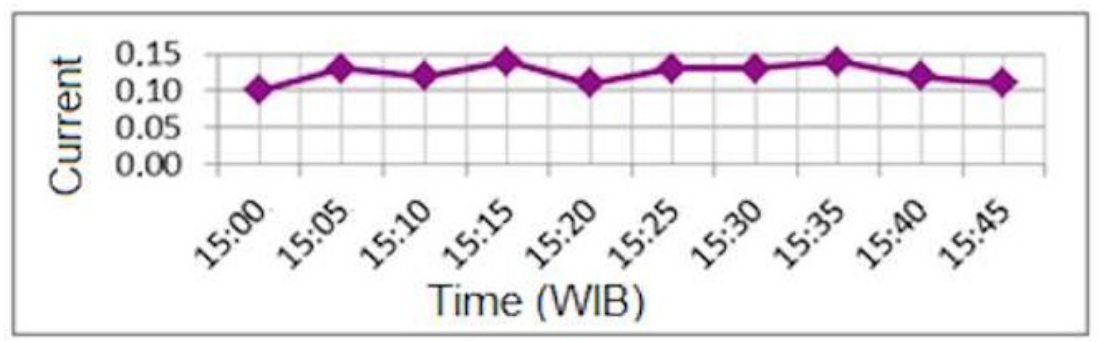

Fig. 6. Graph of current and time of generator with water turbine.

Figure 5 informs that the initial battery voltage of $10.5 \mathrm{~V}$. After charging for almost $1 \mathrm{~h}$ the battery voltage becomes $10.77 \mathrm{~V}$, the voltage rises because there is a charging process. Continues in Figure 6, the flow and time graph of the generator with a water turbine at the rotational speed of the generator $200 \mathrm{rpm}$ to $240 \mathrm{rpm}(1 \mathrm{rpm}=1 / 60 \mathrm{~Hz})$ is the most effective filling of the accumulator. At a rotational speed of $240 \mathrm{rpm}$ the voltage is with a current of $0.14 \mathrm{~A}$, while for the lowest rotating speed is $204 \mathrm{rpm}$ with a current of $0.1 \mathrm{~A}$.

\section{Conclusion}

Pico hydro is a power plant with water resources. The turbine rotary drive in Pico hydro is water which is an alternative energy. The generator works at a speed of $500 \mathrm{rpm}$ and a frequency of $50 \mathrm{~Hz}$. Planning produces pure AC voltage of $36.85 \mathrm{~V}$ and for the measurement results produce a voltage of $35.1 \mathrm{~V}$ with $95 \%$ manufacturing efficiency. The greater number of turns, maximum flux, and the number of coils on the generator also affects the voltage produced. The greater the diameter of the email wire, the greater the ability to conduct current carrying capacity. After going through the rectifier of the voltage of $35.1 \mathrm{~V} \mathrm{AC}$ dropped to $31.1 \mathrm{~V} \mathrm{DC}$, a decrease of $11.4 \%$ is due to pure diode losses without any addition. Water discharge during field testing is $0.01 \mathrm{~m}^{3} \mathrm{~s}^{-1}$ or $10 \mathrm{~L} \mathrm{~s}^{-1}$, which can rotate water turbines with a speed of $200 \mathrm{rpm}$. If the water discharge is getting bigger, the turbine rotational speed will be greater. This is directly proportional between the water flow and rpm. Charging the battery voltage must be more than $12 \mathrm{~V}$, the generator must be turned at least $200 \mathrm{rpm}$ with a voltage of $14 \mathrm{~V}$ so that it can be used for charging batteries.

\section{References}

1. B.A. Nasir. Energy Procedia, 50:19-29(2014). https://www.sciencedirect.com/science/article/pii/S1876610214007395 
2. Y.R. Pasalli, A.B. Rehiara, Procedia Environ. Sci., 20:55-63(2014).

https://www.sciencedirect.com/science/article/pii/S1878029614000103

3. V. Goudar, Z. Ren, P. Brochu, M. Potkonjak, Q. Pei. IEEE Sens. J., 14,7: 2084-2091(2014). https://ieeexplore.ieee.org/document/6663627

4. A. Khaledian, M. Golkar, J. Appl. Res. Technol., 15,4:371-377(2017). https://www.sciencedirect.com/science/article/pii/S1665642317300615

5. P.A. Michael, C.P. Jawahar. Energy Procedia, 117:163-171(2017). https://www.sciencedirect.com/science/article/pii/S1876610217323263

6. D. Zappalá, N. Sarma, S. Djurović, C.J. Crabtree, A. Mohammad, P.J. Tavner. Renew. Energy, 131:14-24(2019). https://www.sciencedirect.com/science/article/pii/S096014811830750X

7. A. Lubis. Jurnal Teknik Lingkungan, 8,2:155-162(2007). [in Bahasa Indonesia] http://ejurnal.bppt.go.id/index.php/JTL/article/view/420

8. B. Hartadi. Jurnal Al Ulum Sains dan Teknologi, 1,1:1-8(2015). [in Bahasa Indonesia] https://ojs.uniska-bjm.ac.id/index.php/JST/article/view/289

9. M. Aslam, M.R. Kirom, R.F. Iskandar. e-Proceeding of Engineering, 2,3:73237329(2015). [in Bahasa Indonesia] https://openlibrary.telkomuniversity.ac.id/pustaka/104339/rancang-bangun-turbinbulb-pada-sistem-pembangkit-listrik-tenaga-pikohidro-di-dalam-saluran-pipa-air.html

10. Andika, A. Hamzah. Jom FTEKNIK Volume 5,1:1-8(2018). [in Bahasa Indonesia] https://www.neliti.com/publications/200337/perancangan-dan-pembuatan-generatorfluks-radial-tiga-fasa-magnet-permanen-kecep

11. W.B. Pramono, Warindi, A. Hidayat. Perancangan mini generator turbin angin 200 $W$ untuk energi angin kecepatan rendah. [Design of $200 \mathrm{w}$ wind turbine generator for low speed wind energy]. Paper Presented in Seminar Nasional Teknologi dan Informatika (SNATIF) (Kudus, Indonesia, 2015). Prosiding SNATIF ke-2, 421428(2015). [in Bahasa Indonesia]

https://www.neliti.com/publications/174354/perancangan-mini-generator-turbinangin-200-w-untuk-energi-angin-kecepatan-renda

12. S. Lajqi, N. Lajqi, B. Hamidi. International Journal of Contemporary ENERGY, 2,1:1-13(2016). https://pdfs.semanticscholar.org/28a1/b43671a10c5acf453060b5359890b01491fc.pdf 